\title{
Development and maturation of mango fruits cv. 'Ubá' in Visconde do Rio Branco, Minas Gerais State, Brazil
}

\author{
Danielle Fabíola Pereira da Silva ${ }^{1 *}$, Luiz Carlos Chamhum Salomão ${ }^{2}$, Laísse Danielle Pereira ${ }^{1}$, \\ Karminne Dias do Valle ${ }^{1}$, Hildeu Ferreira da Assunção ${ }^{1}$, Simério Carlos Cruz ${ }^{1}$
}

10.1590/0034-737X201865060006

\begin{abstract}
Several criteria have been used to determine fruit maturity, which are based on the appearance and chemical composition of the produce at harvest time. The objective of this study was to evaluate the physical, chemical and physiological changes that occur during the development of mango cv. 'Ubá', aiming to determine the stages of fruit development until complete maturation. The experiment was carried out in an approximately 30 -year-old orchard in Visconde do Rio

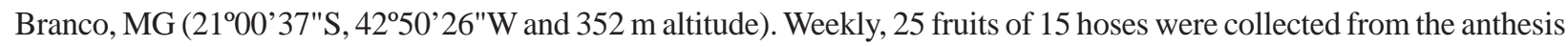
to the complete maturation in the plant. Samplings took place from August 2007 to January 2008. The characteristics evaluated were length, smaller and larger diameter; $\mathrm{CO}_{2}$ production; color parameters $\mathrm{L}^{*}, \mathrm{a}^{*}$, and $\mathrm{b}^{*}$ of skin and pulp; fresh and dry mass (fruit, skin, pulp, and seed); solute leakage; pulp firmness; soluble solids (SS); titratable acidity (TA); SS/TA ratio; Vitamin C; carotenoids, starch, and soluble sugars. The development of mango fruit cv. 'Ubá' took 23 weeks. The developmental pattern fit a simple sigmoidal model. Fruits attached to the plant reached the respiratory climacteric stage between 20 and 21 weeks after anthesis.
\end{abstract}

Keywords: Mangifera indica L; Growth curve; harvest point.

\section{RESUMO}

\section{Desenvolvimento e maturidade de frutos de mangueira 'Ubá' em Visconde do Rio Branco, Minas Gerais}

Vários critérios têm sido utilizados na determinação da maturidade de frutos, baseados na aparência e na composição química do produto na época da colheita. Objetivou-se avaliar as mudanças físicas, químicas e fisiológicas ocorridas durante o desenvolvimento da manga 'Ubá', visando estabelecer as fases de desenvolvimento do fruto para o completo amadurecimento. O experimento foi desenvolvido em pomar com cerca de 30 anos de idade em Visconde do Rio Branco,

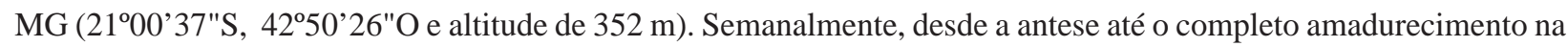
planta, foram coletados 25 frutos de 15 mangueiras. As amostragens ocorreram de agosto de 2007 a janeiro de 2008. As características avaliadas foram: comprimento, menor e maior diâmetro; produção de $\mathrm{CO}_{2}$; parâmetros de cor $\mathrm{L}^{*}, \mathrm{a}^{*}$ e b* da casca e da polpa; massa fresca e seca (fruto, casca, polpa e semente); extravasamento de solutos; consistência da polpa; sólidos solúveis (SS); acidez titulável (AT); ratio (razão SS/AT); vitamina C; carotenoides, amido e açúcares solúveis. O desenvolvimento da manga 'Ubá' estendeu-se por 23 semanas. O padrão de desenvolvimento ajustou-se a um modelo sigmoidal simples. O climatérico respiratório dos frutos ligados à planta foi atingido entre a $20^{\mathrm{a}} \mathrm{e}$ a $21^{\mathrm{a}}$ semana após a antese.

Palavras-chave: Mangifera indica L; curva de crescimento; ponto de colheita.

Submitted on April $2^{\text {nd }}, 2018$ and accepted on September 25 2 th, 2018.

${ }^{1}$ Universidade Federal de Jataí, Unidade Acadêmica Especial de Ciências Agrárias, Jataí, Goiás, Brazil. daniellefpsilva@gmail.com; laissedaniellep@gmail.com, karminnevalle@gmail.com, hildeu@yahoo.com.br; simerio_cruz@yahoo.com.br

${ }^{2}$ Bolsista de produtividade do CNPq. Universidade Federal de Viçosa, Departamento de Fitotecnia, Viçosa, Minas Gerais, Brazil. CNPq Scholarship Holder. salomao@ufv.br *Corresponding author: daniellefpsilva@ gmail.com 


\section{INTRODUCTION}

Mango is cultivated in nearly all regions of Brazil, with potential for increase in both the cultivated area and productivity. In Minas Gerais, specifically in the Zona da Mata Region, the cultivar 'Ubá' stands up, growing spontaneously in practically all the municipalities of the region. The fruits of this cultivar are mainly used in industrial processing, but they are accepted for fresh consumption.

The evaluation of the developmental pattern of a fruit from flowering helps in determining maturity and harvest indices (Matarazzo et al., 2013). Several indices used during development are based on appearance (shape, diameter, color) and chemical composition (soluble solids, titratable acidity) (Biale \& Young, 1964). Filgueiras et al. (2000) discussed that the physical indices of mango harvest are mostly based on characteristics of shape and appearance of the fruit, which can be visually perceived without using destructive methods such as: skin color and appearance: dark green color changes to bright green, wax-free; lenticels: close with fruit maturity; apex shape: full and round; beak shape: begins to appear in some cultivars; and shoulder shape: in immature fruit is in line with the stalk insertion, elevating above the stalk attachment in mature fruit.

The stages of fruit development are marked by changes in structure, physiology, and biochemistry of cells, leading to maturity, senescence and ultimately tissue death. Mango ripening is characterized by pulp softening, changes in skin and pulp colors, reduction in astringency, and development of aroma and flavor of fruits (Chitarra \& Chitarra 2005).

'Ubá' mango is usually harvested with green skin color, but physiologically mature, that is, in the pre-climacteric stage. If fruit are harvested before this stage, they do not reach good quality for consumption. Therefore, the distinction between a physiologically mature and immature fruit at harvest and the assessment of the green mango quality at harvest is very important for the market (Saranwong et al., 2004).

Moraes et al. (2000) analyzed the physical and chemical changes in 'Ubá' mango from the $15^{\text {th }}$ week after flowering to full maturity. The respiratory rate of the fruits did not change significantly until the $23^{\text {rd }}$ week, and then a subsequent increase of more than $100 \%$ occurred, corresponding to the climacteric peak. Soluble solids accumulation was low until the $23^{\text {rd }}$ week, with average Brix of $7^{\circ}$, and then a subsequent increase to $20^{\circ}$, on average, on the $25^{\text {th }}$ week of evaluation. The titratable acidity decreased over the study period, consequently, the soluble solids/titratable acidity ratio increased more rapidly between the $22^{\text {nd }}$ and $24^{\text {th }}$ weeks. From the $15^{\text {th }}$ week after flowering, 'Ubá' mango fruits had already normal maturity capacity, that is, they had already reached physiological maturity (Moraes, 1988).

All aspects of mango development are directly or indirectly influenced by the environment. Thus, understanding plant responses to environmental variations is crucial for management that is suitable to the prevailing conditions, aiming to improve fruit quality and maximize productivity.

No references were found in the literature on the complete development of 'Ubá' mango. Therefore, the objective of this work was to characterize the physical, chemical, and physiological changes during the development of mango (Mangifera indica L.) cultivar 'Ubá', from anthesis to complete maturity in the plant.

\section{MATERIAL AND METHODS}

The field experimental phase of this study was conducted in a grafted mango orchard of about 30 years old, in Sementeira Farm, belonging to the Universidade Federal de Viçosa, in the municipality of Visconde do Rio Branco, MG (2100'37"S, 4250'26"W; 352 m altitude). Weekly, from anthesis $(09 / 08 / 2007)$ to complete maturity of the fruit in the plant (10/01/2008), 25 fruits were collected from 15 previously identified 'Ubá' mango trees. The experiment was arranged in a completely randomized design (CRD), with 23 treatments (harvest times) and 5 replicates. The experimental unit consisted of 5 fruits. Samples were collected from August 2007 to January 2008. After harvest, fruits were taken for analyses of the physical, chemical and physiological characteristics to the Laboratory of Fruit Analysis of the Fitotecnia (Plant Science) Department of UFV.

Fruits were evaluated individually for length, smaller and larger diameter (digital caliper and results expressed as mm), skin and pulp color (Minolta CR10 digital colorimeter), and pulp firmness (round-tipped digital penetrometer, $12 \mathrm{~mm}$ diameter, results expressed as $\mathrm{kPa}$ ). Fresh and dry mass (fruit, skin, pulp, and seed), soluble solids content (SS-digital refractometer), titratable acidity (AT-AOAC, 2012), Ratio (soluble solids/titratable acidity ratio), electrolyte leakage (from the $9^{\text {th }}$ week after anthesisonwards WAA) analysis followed the methodology of Serek et al. (1995), with modifications); vitamin C in pulp was determined according to AOAC (2012), carotenoids in pulp was determined according to Lichtenthaler (1987) with modifications, and carbohydrates in pulp was determinied according to Salomão (1995).

Fruit $\mathrm{CO}_{2}$ production was determined by gas chromatography from the $1^{\text {st }}$ WAA. For this purpose, the fruits were packed in airtight glass jars. Sixty minutes later, $1.0 \mathrm{~mL}$ aliquots of jar atmosphere were withdrawn with a syringe and injected into a Gow Mac Series 550P gas 
chromatograph equipped with a thermal conductivity detector and an aluminum column filled with Porapak Q.

Experimental data as a function of time were analyzed by ANOVA and regression analysis. For some characteristics, non-linear sigmoid regression models with three and four parameters were used to explain physiologically the fruit development. The non-linear models were chosen based on the coefficient of determination and the potential to explain the biological phenomenon.

The program used to analyze the data was the System of Statistical and Genetic Analysis (SAEG, 2007).

\section{RESULTS AND DISCUSSION}

The length measurements fitted to a simple sigmoidal model in response to time variation (Figure 1A). The point of minimum curvature occurred at $3.08^{\text {th }}$ WAA, marking the beginning of significant gains in fruit growth (Figure $1 \mathrm{~A})$. The maximum length growth rate was at $7.7^{\text {th }}$ WAA, with weekly gain of $8.89 \mathrm{~mm}$. The point of maximum curvature occurred at $12.3^{\text {rd }}$ WAA, indicating that from that week onwards length began to stabilize.

Alves et al., (2012) evaluated the development of sweet passion fruit in Viçosa, Minas Gerais, and found that the maximum growth rate for fruit length occurred at 12.44 DAA, with daily gain of $2.61 \mathrm{~mm}$.

The point of minimum curvature for ventral and cross diameters occurred at $2.54^{\text {th }}$ and $2.17^{\text {th }}$ WAA, respectively, marking the beginning of expressive gains in fruit size (Figure 1A). The points of maximum curvature for the ventral and cross diameters occurred at $13.86^{\text {th }}$ and $13.3^{\text {rd }}$ WAA, respectively, indicating that from these weeks the size began to stabilize.

The mean ventral and cross diameters fitted to a sigmoidal model in response to time variation (Figure 1B). Lucena (2007), studying the growth curve of mango cv. Tommy Atkins in San Francisco Valley, Petrolina, PE- Brazil, found that longitudinal, ventral and cross diameters had quadratic fit as a function of time variation. Fruits increased in size up to the $10^{\text {th }}$ WAA, when the length was assessed, and up to the $11^{\text {th }}$ WAA, when ventral and cross diameters were assessed. After these times, these characteristics remained practically constant.

Although not all fruits change color during ripening, this is one of the characteristics most associated to harvesting point and maturity for consumption (Tucker, 1993). This statement is particularly true for mango harvesting, especially in relation to the color of the skin. Figure 1C shows that the difference in skin color ( $\ddot{\mathrm{AE}}$ ) of 'Ubá' mango increased 9.9 times from the $9^{\text {th }}$ WAA ( $\mathrm{ÄE}=$ 2.7) and underwent deeper changes from the $21^{\text {st }}$ WAA, with color difference of 12.6 in the $23^{\text {rd }}$ WAA.
The difference in pulp color doubled from the $9^{\text {th }}$ to the $14^{\text {th }}$ WAA, from 4.0 to 8.6 , and from there, there was a high increase, reaching 34.2 on the $23^{\text {rd }}$ WAA (Figure $1 \mathrm{C}$ ).

Mango skin hue angle fitted to a sigmoidal model (Figure 1D). The point of minimum curvature occurred at the $21.8^{\text {th }}$ WAA $\left(\mathrm{h}=102.8^{\circ}\right)$, marking the beginning of the transition from green to yellow. On the $23^{\text {rd }}$ WAA, the skin was deep yellow $\left(h=82.9^{\circ}\right)$. The point of maximum curvature was estimated at $26.1^{\text {st }}$, indicating lack of stabilization during the experimental period. Fruit color varies markedly with intensity and amount of sunlight exposure (Morais et al., 2004). Therefore, the position in the plant and the season influence significantly color development, which can be the likely reason for the high standard deviation of the observed means.

Similar results were found by Moraes et al. (2000) studying the development of 'Ubá' mango fruit in Visconde do Rio Branco - MG. The authors found that from the $21^{\text {st }}$ week after flowering (WAA), using the Munsell color system, the skin color changed from hue 5GY (greenyellow) to hue $5 \mathrm{Y}$ (yellow), and finally reached hue $10 \mathrm{YR}$ (orange) between the $23^{\text {rd }}$ and $24^{\text {th }}$ WAA.

Degradation of chlorophyll in the pericarp and the synthesis and/or manifestation of carotenoid pigments take place gradually, and the green color disappears with the fruit development (Medeiros et al., 2011).

According to O'Hare (1995), the beginning of the climacteric in mango shows intense chlorophyll degradation in the skin (Figure 3D), as on the 21.8 ${ }^{\text {th }}$ WAA, a rapid change of green into yellow began practically coinciding with the climacteric peak (Figure 4C).

The hue angle of the pulp (Figure 1D) fitted to a sigmoidal model. The yellowish-green color of the pulp was reached on the $15^{\text {th }}$ WAA $\left(\mathrm{h}=100.6^{\circ}\right)$. The yellow color of the pulp $\left(\mathrm{h}=90^{\circ}\right)$ was reached on the $18.3^{\text {rd }}$ WAA. At $23^{\text {rd }}$ WAA, the color of the pulp was $73.9^{\circ}$, indicating a yellow-orange color.

The points of minimum (PC min) and maximum (PC max) curvature were estimated as occurring on the $44.4^{\text {th }}$ WAA and $0.9^{\text {th }}$ WAA, respectively, beyond the experimental period and indicating absence of stable phase in pulp color change. Similar to size, accumulation of fresh mass of fruit, pulp, skin, and seed fitted to a simple sigmoidal development pattern (Figure 2A).

The point of minimum curvature occurred at $7.4^{\text {th }}$ WAA, marking the beginning of expressive gains in the accumulation of fruit fresh mass (Figure 2A). The derivative of the adjustment equation showed that the highest accumulation rate of fresh mass occurred on the $11.4^{\text {th }}$ WAA, with weekly gain of $19.87 \mathrm{~g}$. The point of maximum curvature was on the $15.4^{\text {th }}$ WAA, indicating that from that week on the accumulation of fresh mass began to stabilize, corresponding to $88 \%$ of the maximum 
accumulation. These results are similar to those reported by Moraes et al. (2000) for development of 'Ubá' mango in the Zona da Mata Region. The authors found that from the $15^{\text {th }}$ week after flowering, accumulation of fruit fresh mass stabilized.

Silva et al. (2013) studied the growth curve and respiratory pattern of peach genotypes in a subtropical region. They reported that the fruit fresh mass increased
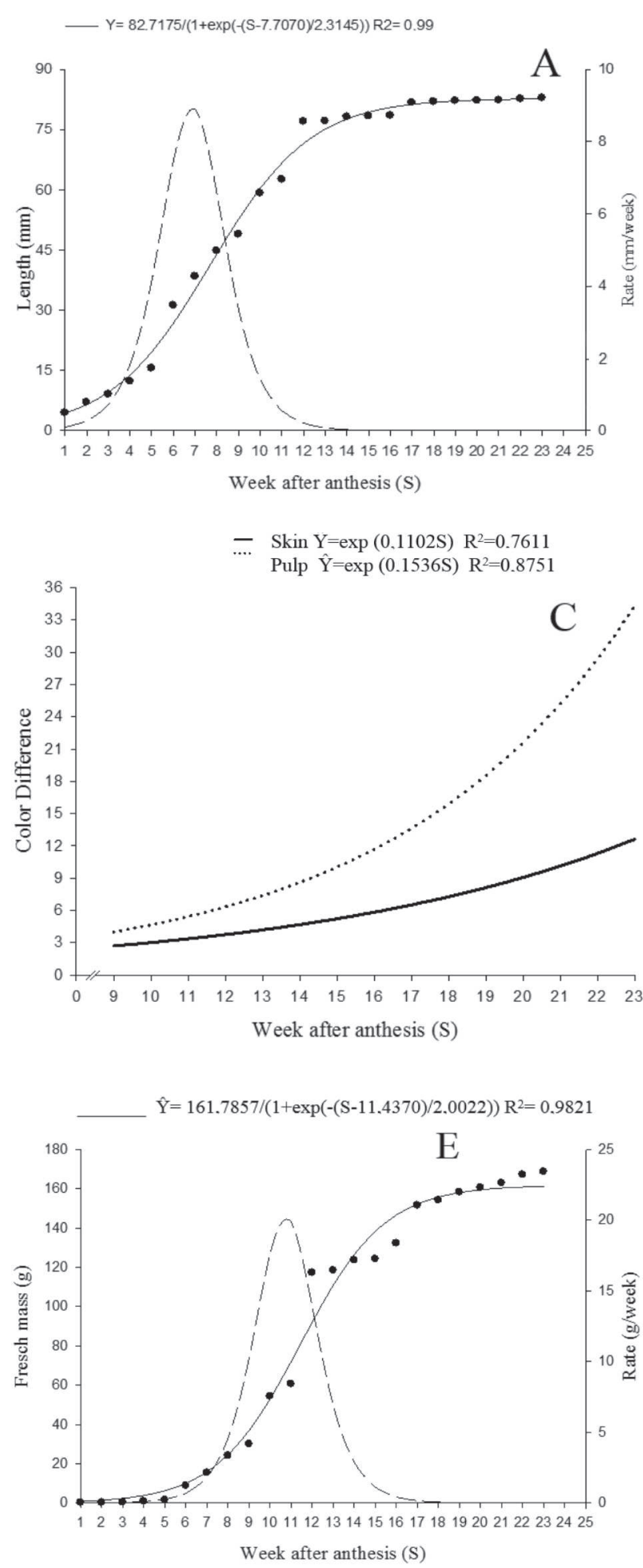

slowly at the beginning of the cycle and, between 60 and 75 days after anthesis (DAA), doubled from $13.31 \pm 1.43 \mathrm{~g}$ to $26.14 \pm 3.71 \mathrm{~g}$. These results are lower than those found in the present study, where the point of minimum curvature occurred on average 51.8 DAA, indicating the beginning of expressive gains in the fruit fresh mass accumulation.

Figure 2A shows the point of minimum curvature of the fresh mass on $6.86^{\text {th }}, 5.59^{\text {th }}$, and $9.73^{\text {th }}$ WAA for pulp, $\begin{array}{llll}\text { Co } & \text { Larger diameter } \hat{Y}=59,3058 /(1+\exp (-(\mathrm{S}-8,1985) / 2,8295)) & \mathrm{R}^{2}=0,9883 \\ - & \text { Co } & \text { Smaller diameter } \hat{\mathrm{Y}}=62.5000 /(1+\exp (-(\mathrm{S}-7.7507) / 2.7885)) & \mathrm{R}^{2}=0.9852\end{array}$
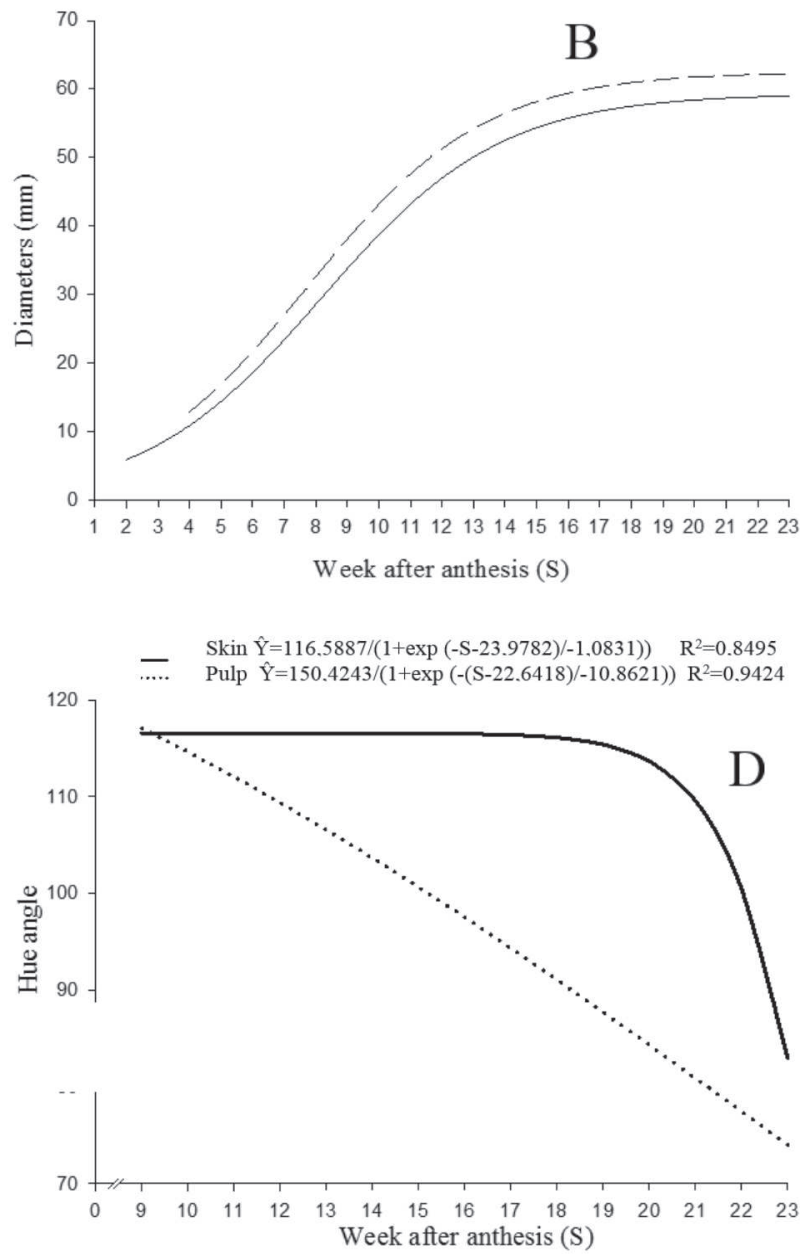

Figure 1: Observed and estimated length increases (A), ventral and cross diameters (B), increase in fresh mass accumulation (C); estimate of color difference, C: skin and pulp (ÄE); D: Hue angle of skin and pulp E: fruit fresh mass over development of 'Ubá' mango as a function of time (S). 
skin, and seed, respectively, and the point of maximum curvature, that is, the beginning of stabilization of fresh mass accumulation occurring only on $15.19^{\text {th }}, 20.25^{\text {th }}$, and $13.8^{\text {th }}$ WAA, respectively. The maximum values of mass accumulation reached by pulp, ski, and seed were 101.13, 34.75 , and $29.09 \mathrm{~g}$, respectively.

From the ninth week on, when it was possible to separate the fruit parts, the pulp already stood out over the other components, reaching up to $62.49 \%$ of the total fruit mass.

On the $17^{\text {th }}$ WAA, when the fruit reached physiological maturity, we found that the yield of pulp, skin, and seed was $63.47 ; 17.35$, and $19.18 \%$, respectively. These results confirm those reported by Rocha (2009) for several accessions of 'Ubá' mango with pulp, skin, and seed yields of $65.28,20.03$, and $15.76 \%$, respectively. Folegatti et al. (2002) pointed out that the minimum acceptable pulp yield to select a cultivar for industry is $60 \%$, and the fruit analyzed in this study yielded above these requirements.

Figure $2 \mathrm{~B}$ shows the point of minimum curvature of fruit dry mass on the $8.78^{\text {th }}$ WAA, indicating the beginning of expressive gains in accumulation. The point of maximum curvature was on the $22.58^{\text {th }}$ WAA, showing that from that week the accumulation of dry matter began to stabilize. This initial stabilization occurred near the $23^{\text {rd }}$ WAA, when the fruits could be considered mature, as opposed to the accumulation of fresh mass that stabilized from the $15.4^{\text {th }}$ WAA (Figure 2A).

It is clear that pulp was the component accounting for the greatest amount of dry mass in the fully developed fruit (Figure 2B), as well as observed for jabuticaba fruit (Magalhães, 1991). Untill near the $11^{\text {th }}$ WAA, the skin of 'Ubá' mango accumulated more dry mass than the seed, then, from there on, the seed surpassed the skin mass until the harvest period.

The point of minimum curvature occurred on $9.14^{\text {th }}$, $5.3^{\text {th }}$, and $10.26^{\text {th }}$ WAA for pulp, skin, and seed, respectively (Figure 2B). On the other hand, the point of maximum curvature occurred on $22.55^{\text {th }}$ and $20.29^{\text {th }}$ WAA for skin and seed, respectively. The pulp dry mass showed the maximum point of curvature on the $31.32^{\text {th }}$ WAA, indicating no stabilization during the experimental period.

Solute leakage was adjusted to the linear model as a function of time (Figure 2D), being directly proportional to the development of the fruit, that is, there is greater solute leakage as fruit develops. This is possibly caused by cell expansion during fruit development.

Cell expansion, as well as maturity, causes significant changes in membrane structure and cell wall, leading to the increase in solute leakage. For Kader (1999), one of the most remarkable changes that occur during ripening and subsequent senescence of fruits is solute leakage, which confirms the findings of this work.
Pulp firmness reduced gradually until the $14^{\text {th }}$ WAA (Figure 2E). From the $15^{\text {th }}$ WAA onwards, there was increase in the rate of firmness loss, as shown by the increase in the curve slope.

Filgueiras et al. (2000) recommended harvest of 'Tommy Atkins' mango with firmness of $129.36 \mathrm{~N}$, while Medlicott \& Reynolds (1988) recommend the range of 107.84-127.45 $\mathrm{N}$, and Alves et al. (2002) recommended firmness of 129.41 $\mathrm{N}$. As we previously mentioned, the harvest of 'Ubá' mango can be done from the $17^{\text {th }}$ WAA (physiological maturity). During this period, the estimated pulp firmness was 2015.6 $\mathrm{kPa}$ (Figure 2E).

At the end of fruit development, the sharp loss of firmness in 'Ubá' mango may be due to maturation and degradation of the cell wall and middle lamella.

Soluble solids increased slowly up to the $17^{\text {th }}$ WAA and rapidly thereafter (Figure $3 \mathrm{~A}$ ), from $9^{\text {th }}$ to $17^{\text {th }}$ WAA, the soluble solids content increased from 6.5 to $8.0^{\circ} \mathrm{Brix}$, reaching the maximum content of $24.32^{\circ} \mathrm{Brix}$ on the $23^{\text {rd }}$ WAA. Chitarra \& Chitarra (2005) attributed the increase in SS content during maturation mainly to the hydrolysis of reserve carbohydrates, accumulated during the fruit growth in the plant.

As it was expected, there was a reduction in titratable acidity with mango fruit development (Figure 3B). The citric acid content decreased from $3.49 \%$ on the $9^{\text {th }}$ WAA to $2.33 \%$ on the $17^{\text {th }}$ WAA, when the fruit reached physiological maturity, and to $0.83 \%$ in the fully mature fruit. According to Kader (1999), after harvest and during storage, the concentration of organic acids usually declines because they are used as substrate in respiration or they are transformed into sugars. This transformation is important for flavor (acidity) and aroma, since some of these compounds are volatile.

In fruits of several species, the soluble solids/titratable acidity ratio indicates the stage of physiological maturity (Chitarra \& Chitarra, 2005). This ratio went from 2.57 on the $9^{\text {th }}$ WAA to 2.86 io the $17^{\text {th }}$ WAA, (Figure $3 \mathrm{C}$ ), a period characterized by low content of soluble solids and high titratable acidity. As development advanced, the acidity decreased and soluble solids content increased and, consequently, after the $17^{\text {th }}$ WAA there was a rapid increase between the $21^{\text {st }}$ and $23^{\text {rd }}$ WAA, reaching 42.63 .

Vitamin C decreased over the weeks after anthesis according to a quadratic model (Figure 3D). Kader (1999) observes that ascorbic acid is structurally one of the simplest vitamin components found in plants. It is an acidic sugar lactone that is synthesized in plants from glucose or other simple carbohydrates. For 'Ubá' mango, the contents of vitamin $\mathrm{C}$ in mature fruits are nearly double the values found for other cultivars, as on the $23^{\text {rd }}$ WAA, the vitamin C content was $73.67 \mathrm{mg} / 100 \mathrm{~g}$ of fresh pulp mass, which highlights the high nutritional value of cultivar 'Ubá'. Si- 
milar results were found by Ribeiro (2006), working with 'Ubá' mango at maturity for consumption, with $77.71 \mathrm{mg}$ $100 \mathrm{~g}$ of vit $\mathrm{C}$ per fresh pulp mass, whereas values of 15.69 , 9.79, and $10.54 \mathrm{mg} / 100 \mathrm{~g}$ fresh pulp mass were found for the cultivars Haden, Tommy Atkins, and Palmer, respectively.

Vitamin C contents described in this study are very close to those reported by Subramanyam (1975) for
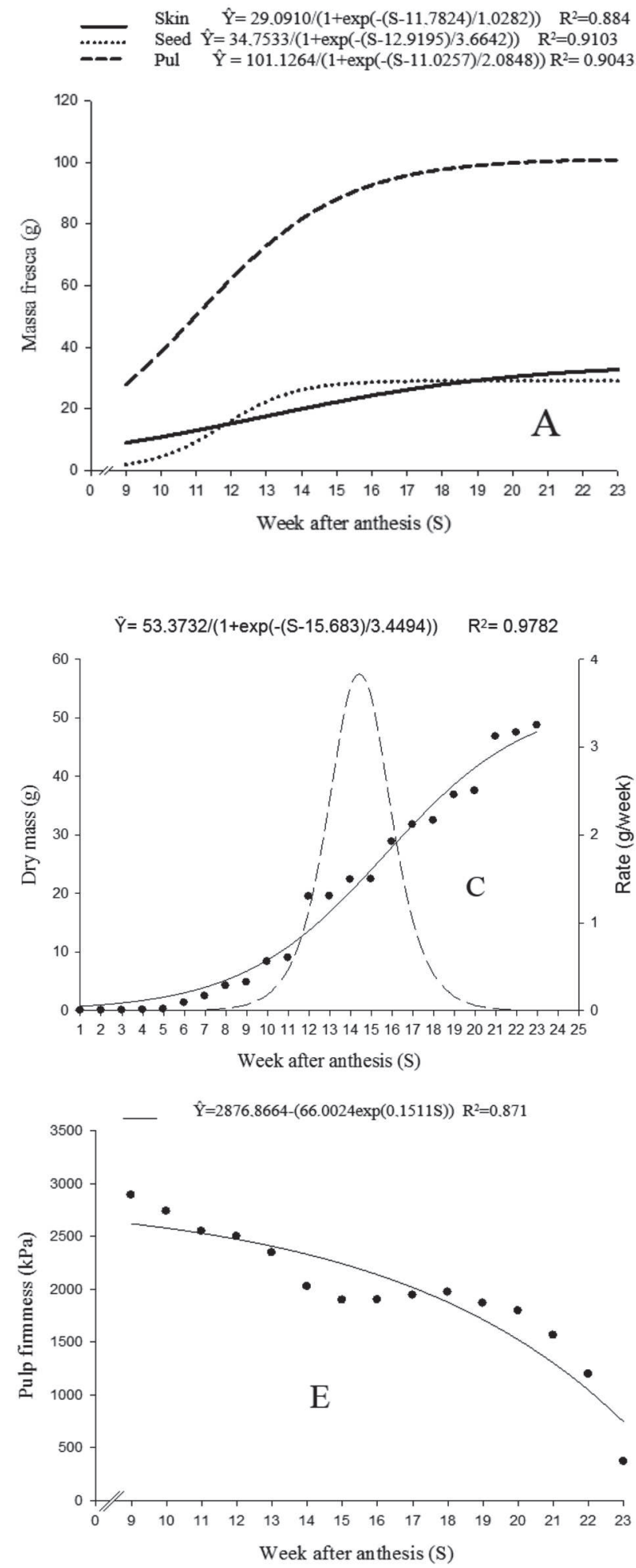

'Alphonso' mango, with average concentrations of 175 and $87.5 \mathrm{mg} / 100 \mathrm{~g}$ of pulp fresh mass obtained for 35 and 112 days after anthesis, respectively. Franco (2003) reported that the mature 'Common' mango has $43 \mathrm{mg} / 100 \mathrm{~g}$ of vitamin $\mathrm{C}$ per fresh pulp mass. On the other hand, Salunke \& Desai (1984) detected only $13.9 \mathrm{mg} / 100 \mathrm{~g}$ of vitamin C per fresh pulp mass in 'Keitt' mango. The differences between the contents found by these studies and our findings can be attributed to different cultivars, orchards located in
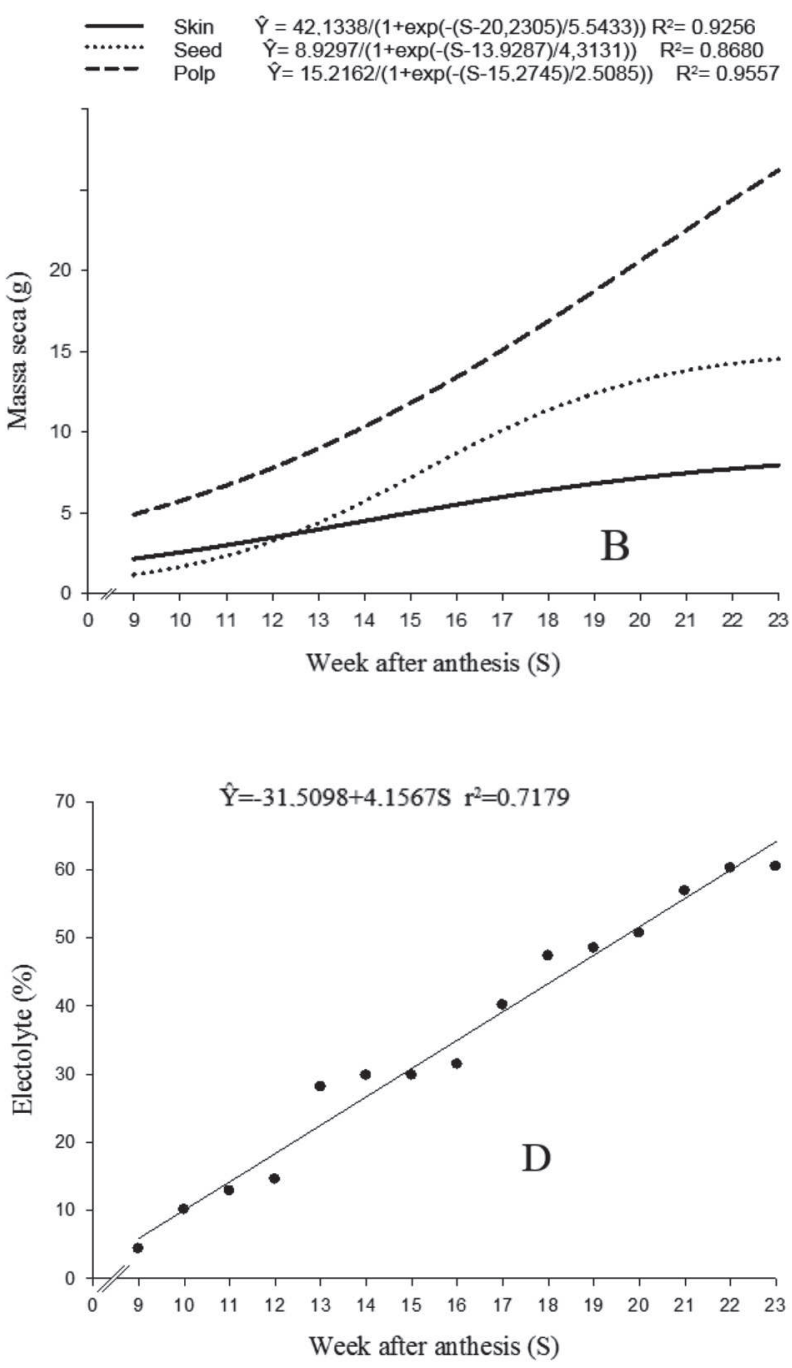

- Figure 2: Estimates of fresh mass (A), dry mass (B) of pulp, skin, and seed; observed and estimated values of dry mass accumulation of fruit (C); (D) and pulp firmness (E) during the development of 'Ubá' mango as a function of time (S).

Rev. Ceres, Viçosa, v. 65, n.6, p. 507-516, nov/dez, 2018 
different climates and regions, different cultural practices, soil characteristics, and use of irrigation.

The means of carotenoids content in response to time variation fitted a quadratic model (Figure 3E). Carotenoids content increased from $0.3 \mathrm{mg} / 100 \mathrm{~g}$ of the fresh pulp mass on the $9^{\text {th }}$ WAA to $2.5 \mathrm{mg} / 100 \mathrm{~g}$ on the $23^{\text {th }}$ WAA. These results corroborate the work of Ribeiro (2006), who assessed mango cultivars and found total carotenoid contents of $2.41 \mathrm{mg} / 100 \mathrm{~g}$ in 'Ubá' mango purchased locally at maturity for consumption, whereas cultivars Haden, Tommy Atkins, and Palmer had carotenoid contents of 1.91, 2.53 , and $2.63 \mathrm{mg} / 100 \mathrm{~g}$ of pulp, respectively (Ribeiro, 2006).

Medlicott \& Reynolds (1988) found total carotenoid values higher than $0.5 \mathrm{mg} / 100 \mathrm{~g}$ of fresh pulp mass for 'Tommy Atkins' mango. Salunke \& Desai (1984), among several cultivars of ripened mangoes, found variation in total carotenoid content from 0.9 to $9.2 \mathrm{mg} / 100 \mathrm{~g}$ of fresh pulp mass. Matarazzo et al. (2013) point out that the levels
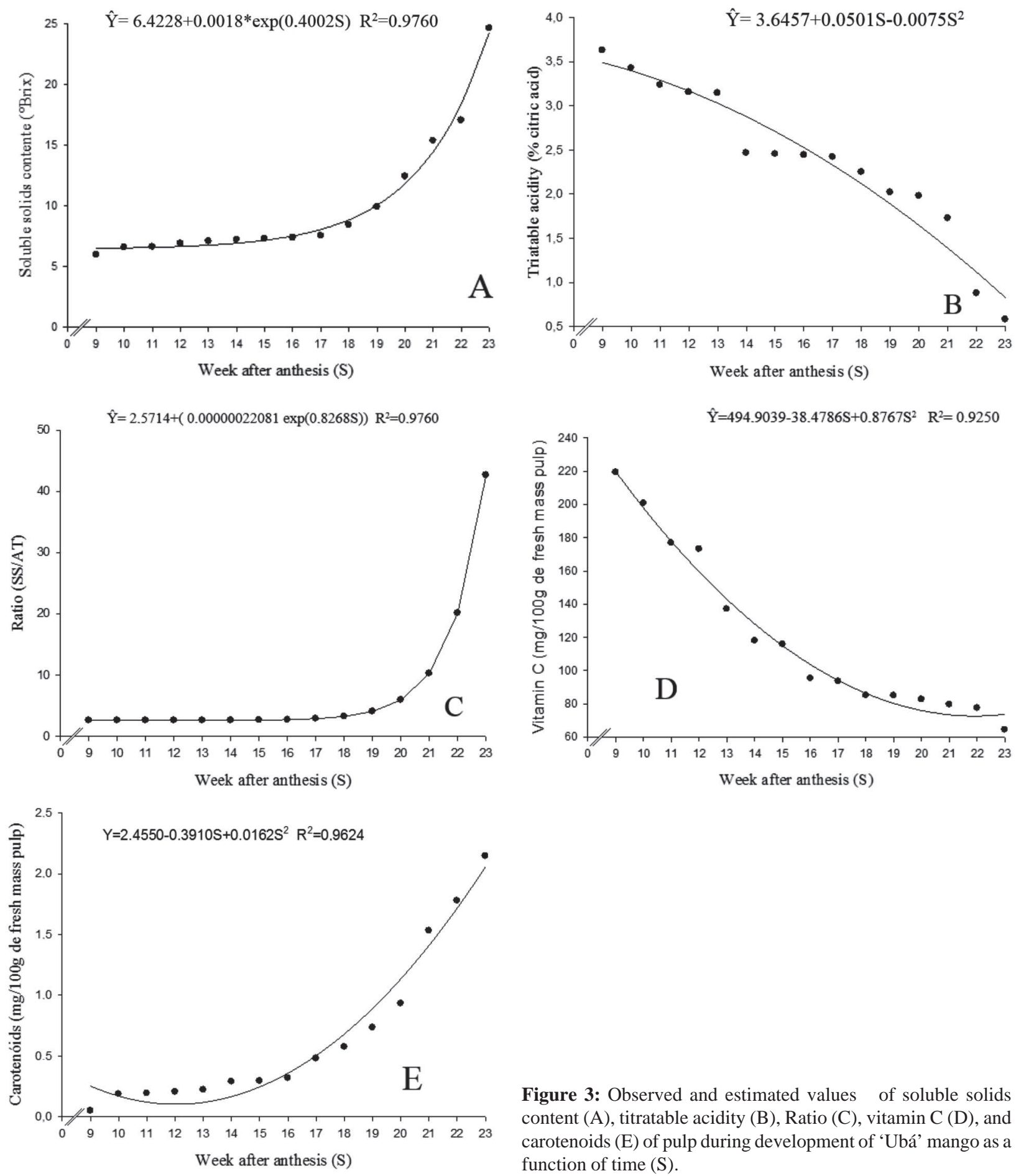

Figure 3: Observed and estimated values of soluble solids content (A), titratable acidity (B), Ratio (C), vitamin C (D), and carotenoids (E) of pulp during development of 'Ubá' mango as a function of time $(\mathrm{S})$. 
of these pigments can be influenced by the season, geographical location, harvest conditions, and other factors.

Subbarayan \& Cama (1970) working with 'Alphonso' mango in the stages immature, partially mature, and mature, found carotenoid contents of $0.041,3.36$, and $8.92 \mathrm{mg} / 100$ $\mathrm{g}$ of the fresh pulp mass, respectively.

Starch content fitted a quadratic model (Figure 4A). On the $9^{\text {th }}$ WAA, starch was estimated to be $7.32 \%$; during fruit development there was expressive accumulation of starch up to the $17^{\text {th }}$ WAA $(11.87 \%)$, then decreased from that time to complete ripening in the plant. The decrease in starch content from the $17^{\text {th }}$ WAA indicates conversion to sugar (Figure 4A). Subramanyam et al. (1975), studying 'Tommy Atkins' mango development in the plant, observed that starch accumulation is the main activity in the pulp tissues, increasing from $1.5 \%$ after fruit setting to $13 \%$ at full development. However, starch is fully hydrolyzed after harvest and synthesis of total sugars occurs within 8 days. These values may vary with the cultivar, harvest period, cultivation site, and cultivation conditions (Lucena, 2007).

Starch is described as the main carbon reserve used in post-harvest synthesis of sucrose (sugar predominant in mature mango) (Fucks et al., 1980; Subramanyam et al., 1975). However, there is no consensus, since Hubbard et al. (1991) and Castrillo et al. (1992), for example, concluded that the starch content found in the freshly harvested mango was insufficient to provide more than $7 \%$ increase in pulp sugar content for the production of accumulated sucrose during ripening after harvest.

The content of soluble sugars (Figure 4B), the main constituent of soluble solids, followed the same upward trend of SS. Then, similar to soluble solids content (Figure $3 \mathrm{~A})$, the soluble sugar content remained nearly constant until the $7^{\text {th }}$ WAA $(2.02 \%)$. Thereafter, the sugar content increased and, from the $22^{\text {nd }}$ to the $23^{\text {rd }}$ WAA, this increase amounted to $18.5 \%$, with content rising from 5.84 to $6.92 \%$. These results agree with reports by Chitarra \& Chitarra (2005), who found average sugar content varying from 5 to $10 \%$ in ripe climacteric fruit such as mango.

The total carbohydrate content (sugars + starch) on the $23^{\text {rd }}$ WAA was $14.40 \%$. This result corroborates the findings of Ribeiro (2006) in the characterization and evaluation of the antioxidant potential of mango, who reported that the total carbohydrate content in mature 'Ubá' mango was $15.87 \%$.

Data from literature are conflicting with regard to the content of soluble sugars during the development stages and the mature fruit. As noted by Subramanyam et al. (1975) and Awad (1993), there is a predominance of hexoses at the beginning of ripening ( 3 to $6 \%$ ) and sucrose (10 to $12 \%$ ) in the mature fruit. This result was different from that found by Medlicott \& Reynolds (1988), where sucrose was the predominant sugar throughout the ripening of $\mathrm{cv}$. Keitt, accounting for about $57 \%$ of the total sugars content in the ripe fruit. There are also reports of an increase in sugars content during fruit growth and reports of these sugars remaining throughout their development (Hubbard et al., 1991).

To sum up, there is evidence that ripening and accumulation of soluble sugars in mangos start before
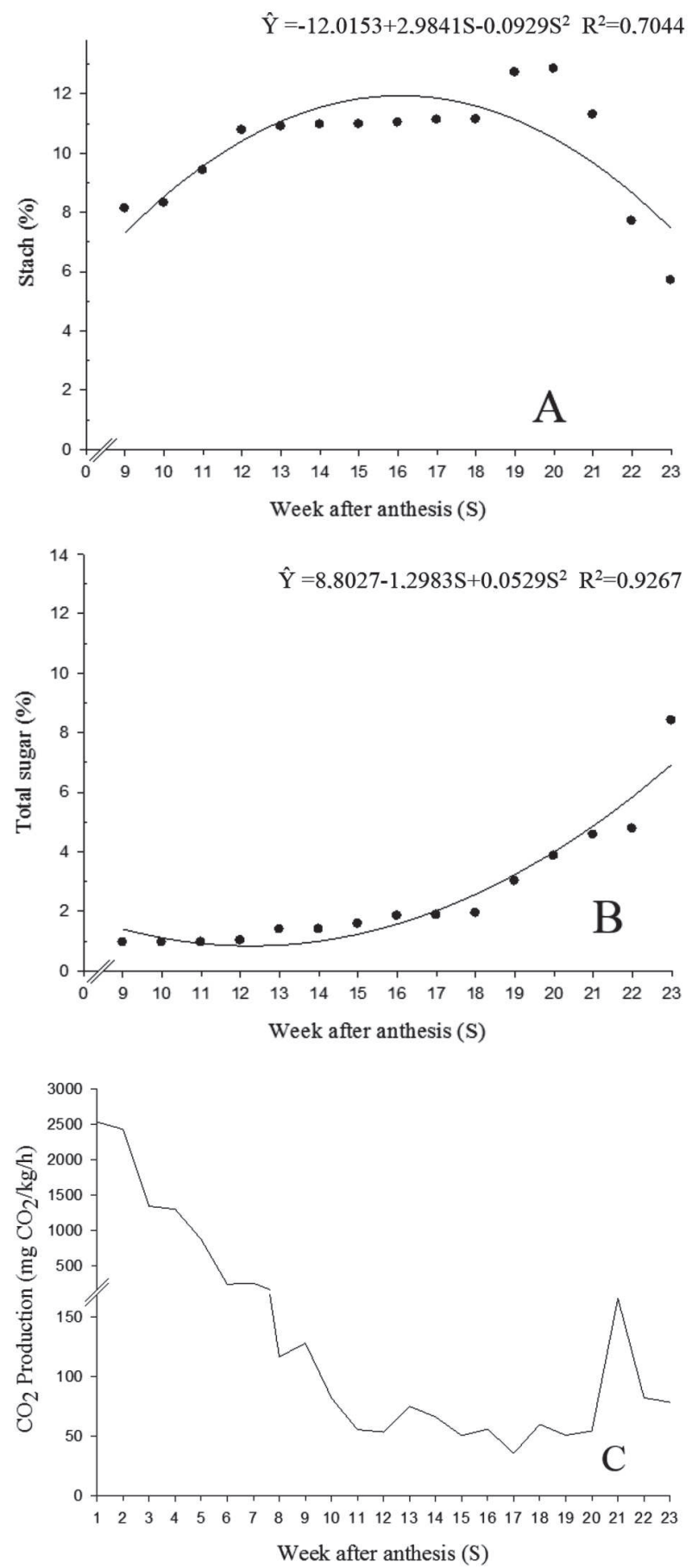

Figure 4: Observed and estimated values of starch content (A), total sugars (B) in fresh pulp mass, and observed values for $\mathrm{CO}_{2}$ (C) production during development of 'Ubá' mango as a function of time (S). 
harvesting and, although starch contents at this time may be considered insufficient, a substantial part of the sugars that compete for the sweetening of ripe fruit is accumulated after harvest. The apparent discrepancy between the data can be due to the studied cultivars, methodologies of analysis, and the maturation stage of the fruit harvested.

In the present work, it is clear that starch synthesis occurs in significant amounts during the fruit formation phase, which explains all the sugar accumulated in the mature fruit, although it takes long time between starch degradation and synthesis of sugar. It is likely that the sweetening of the mango begins with the fruit still attached to the tree and continues after harvesting. Bernardes-Silva et al. (2003) pointed out that it is still unclear what source of carbon is used for the post-harvest synthesis of sucrose.

The $\mathrm{CO}_{2}$ production decreased until around the $11^{\text {th }}$ WAA (Figure 4C). High rates of $\mathrm{CO}_{2}$ were produced from the first to the fifth WAA, decreasing from 2,533.00 mg $\mathrm{CO}_{2} \mathrm{~kg} / \mathrm{h}$ to $879.21 \mathrm{mg} \mathrm{CO} \mathrm{kg} / \mathrm{h}$. Taiz \& Zeiger (2017) argue that high production of $\mathrm{CO}_{2}$ at the beginning of development has no relation to the climacteric or non-climacteric pattern of the fruit and may be related to cell division and radial cell growth.

From the $6^{\text {th }}$ to the $11^{\text {th }} \mathrm{WAA}, \mathrm{CO}_{2}$ production continued to fall, but smoothly, from $245.26 \mathrm{mg} \mathrm{CO} \mathrm{kg} / \mathrm{h}$ to $55.32 \mathrm{mg}$ $\mathrm{CO}_{2} \mathrm{~kg} / \mathrm{h}$. From the $12^{\text {th }} \mathrm{WAA}$ to the $20^{\text {th }} \mathrm{WAA}$, the $\mathrm{CO}_{2}$ production stabilized, with average of $55.60 \mathrm{mg} \mathrm{CO} / \mathrm{kg} / \mathrm{h}$ in the period and, on the $21^{\text {th }}$ WAA, the climateric peak occurred, with production of $165.93 \mathrm{mg} \mathrm{CO} \mathrm{kg} / \mathrm{h}$.

These results are similar to the findings of Moraes et al. (2000) for the development of 'Ubá' mango in Visconde do Rio Branco, MG. They observed climacteric peak (91 $\mathrm{mg} \mathrm{CO} 2 \mathrm{~kg} / \mathrm{h}$ ) of fruits on the $23^{\text {rd }}$ week after flowering.

\section{CONCLUSIONS}

The process of development of mango cv. 'Ubá' in Visconde do Rio Branco took 23 weeks.

The developmental pattern fitted a simple sigmoidal model, with three stages of growth, from $1^{\text {st }}$ to $5^{\text {th }}$ WAA; $6^{\text {th }}$ to $15^{\text {th }}$ WAA; and $16^{\text {th }}$ to $23^{\text {rd }}$ WAA.

Fruits attached to the plant reached respiratory climacteric on the $21^{\text {st }}$ week after the anthesis.

\section{REFERENCES}

Alves RE, Filgueiras HAC, Menezes JB, Assis JS, Lima MAC, Amorim TBF \& Martins AG (2002) Colheita e pós-colheita. In: Genu PJC \& Pinto ACQ (Eds.) A cultura da mangueira. Brasília, Embrapa. p.381-405.

Alves RR, Salomão LCC, Siqueira DL, Cecon PR \& Silva DFP (2012) Desenvolvimento do maracujá doce em Viçosa, Minas Gerais. Revista Ceres, 59:127-133.
AOAC (2012) Official Methods of Analysis of AOAC International. $18^{\circ}$ ed. Washington, AOAC. p. 37-46.

Awad M (1993) Fisiologia pós-colheita de frutos. Nobel, São Paulo. $114 \mathrm{p}$.

Bernardes-Silva APF, Lajolo FM \& Cordenunsi BR (2003) Evolução dos teores de amido e açúcares solúveis durante o desenvolvimento e amadurecimento de diferentes cultivares de manga. Ciência e Tecnologia de Alimentos, 23:116-120.

Biale JB \& Young RE (1964) Growth, maturation and senescence in fruits. Science, 146:880-888.

Castrillo M, Kruger NJ \& Whathey FR (1992) Sucrose metabolism in mango fruit during ripening. Plant Science, 84:45-51.

Chitarra MLF \& Chitarra AB (2005) Pós-colheita de frutos e hortaliças - Fisiologia e Manuseio. Lavras, UFLA. p.785.

Filgueiras HAC, Amorim TBF, Menezes JB \& Alves RE (2000) Colheita e manuseio pós-colheita. In: Filgueiras HAC (Ed.) Manga: pós-colheita. Brasília, Embrapa. p.22-37.

Folegatti MI, Matsuura FCAU, Torrezan F, Botrel N, Souza Filho MSM, Azeredo HMC, Brito ES \& Souza Neto MA (2002) Processamento e frutos. In: Genú PJC \& Pinto ACQ (Eds.) A cultura da mangueira. Brasília, Embrapa. p.409-431.

Franco G (2003) Tabela de composição química dos alimentos. 9a ed. São Paulo, Atheneu. 307p.

Fucks Y, Pesis E \& Zauberman G (1980) Changes in amylase activity, starch and sugar contents in mango fruit pulp. Scientia Horticulturae, 13:155-160.

Hubbard NL, Pharr DM \& Huber SC (1991) Sucrose - phosphate synthase and other sucrose metabolizing enzymes in fruits of various species. Physiologia Plantarum, 82:191-196.

Kader AA (1999) Fruit maturity, ripening, and quality relationships. Acta Horticulturae, 485:203-208.

Lichtenthaler HK (1987) Chlorophylls and carotenoids: Pigments of photosynthetic biomembranes. Methods in Enzymology, 148:349-382.

Lucena EMP, Assis JS, Alves RE, Silva VCM \& Filho JE (2007) Alterações físicas e químicas durante o desenvolvimento de mangas 'Tommy Atkins' no Vale do São Francisco, Petrolina PE. Revista Brasileira de Fruticultura, 29:096-101.

Magalhães MM (1991) Desenvolvimento e carboidratos constituintes do fruto de jaboticaba (Myrciaria jaboticaba Berg cv. 'Sabará'). Dissertação de Mestrado. Universidade Federal de Viçosa, Viçosa. 77p.

Matarazzo PHM, Siqueira DL, Salomão LCC, Silva DFP \& Cecon PR (2013) Lulo (Solanum quitoense LAM) fruits development in Viçosa-MG. Revista Brasileira de Fruticultura, 35:131-142.

Medeiros EAA, Soares NFF, Polito TOS, Sousa MM \& Silva DFP (2011) Sachês antimicrobianos em pós-colheita de manga. Revista Brasileira de Fruticultura, 33:363-370.

Medlicott AP \& Reynolds SB (1988) Harvest maturity effects on mango fruit ripening. Tropical Agriculture, 65:153-157.

Moraes DM (1988) Desenvolvimento e maturação pós-colheita de frutos de manga (Mangifera indica L.) cv. 'Ubá'. Dissertação de Mestrado. Universidade Federal de Viçosa, Viçosa. 36p.

Moraes DM, Puschmann R \& Lopes NF (2000) Respiração e desenvolvimento do fruto de mangueira cv. Ubá. Revista Brasileira de Fruticultura, 22:37- 41.

Morais PLD, Filgueiras HAC, Pinho JLN \& Alves RE (2004) Correlação entre variáveis de crescimento do fruto da mangueira 'Tommy Atkins'. Ciência Agrotécnica, 28:743-747. 
O'Hare TJ (1995) Effect of ripening temperature on quality and compositional changes of mango (Mangifera indica L.) $\mathrm{cv}$ Kensington. Australian Journal of Experimental Agriculture, 35:259-263.

Ribeiro SMR (2006) Caracterização e avaliação do potencial antioxidante de manga (Mangifera indica L.) cultivadas no Estado de Minas Gerais. Tese de Doutorado. Universidade Federal de Viçosa, Viçosa. 149p.

Rocha A (2009) Identificação de embriões zigóticos e nucelares de sementes e caracterização agronômica e molecular de acessos de mangueira 'Ubá'. Tese de Doutorado. Universidade Federal de Viçosa, Viçosa. 117p.

SAEG (2007) Sistema para Análises Estatísticas. Versão 9.1. Viçosa, Fundação Arthur Bernardes. CD-ROM.

Salomão LCC (1995) Efeitos do envoltório plástico no desenvolvimento e na maturação pós-colheita de frutos de banana (Musa sp. AAB) 'Mysore'. Tese de Doutorado. Universidade Federal de Viçosa, Viçosa. 104p.

Salunke DK \& Desai BB (1984) Postharvest biotechnology of fruits. Boca Raton, CRC Press. 168p.

Saranwong S, Sornsrivichai J \& Kawano S (2004) Prediction of ripe-stage eating quality of mango fruit from its harvest quality measured nondestructively by near infrared spectroscopy. Postharvest Biology and Technology, 31:137-145.
Serek M, Tamari G, Sisler EC \& Borochov A (1995) Inhibition of ethylene-induced cellular senescence symptoms by 1 methylcyclopropene, a new inhibitor of ethylene action. Physiologia Plantarum, 94:229-232.

Silva DFP, Silva JOC, Matias RGP, Ribeiro MR \& Bruckner CH (2013) Curva de crescimento e padrão respiratório de frutos de genótipos de pessegueiro em região de clima subtropical. Revista Brasileira de Fruticultura, 35:642-649.

Subbarayan JJ \& Cama HR (1970) Carotenoids in 3 stages of ripening of mango. Journal of food science, 35:263-265.

Subramanyam H, Krishnamurthy S \& Parpia HAB (1975) Physiology and biochemistry of mango fruit. Advances in Food Research, 21:223-305.

Taiz L \& Zeiger E (2017) Fisiologia vegetal. 6 ${ }^{\mathrm{a}}$ ed. Porto Alegre, Artmed. 719p.

Tucker GA (1993) Introduction. In: Seymour GB, Taylor JE \& Tucker GA (Eds.) Biochemistry of fruit ripening. London, Chapman \& Hall. p.01-51. 